\title{
THE DEVELOPMENT AND EVALUATION OF AN IMPROVED CLOVERLEAF MODEL FOR THE ASSESSMENT OF TECHNOLOGY READINESS FOR COMMERCIALISATION
}

\author{
R. Oosthuizen and A.J. Buys \\ Department of Engineering and Technology Management \\ University of Pretoria \\ roosth@,hotmail.com; ajbuys@up.ac.za
}

\begin{abstract}
Technology commercialisation is the process that converts technology that was developed for the government, e.g., defence technology, to commercial use, thereby benefiting the wider community. As technology commercialisation is a high risk and expensive process, care must be taken to commercialise only those technologies with the best chances for success. Heslop, McGregor \& Grifith [1] developed the Cloverleaf Model to assess technology readiness for commercialisation. This model is evaluated and improved for use in the South African environment.
\end{abstract}

\section{OPSOMMING}

Die kommersialisering van tegnologie is die proses waardeur tegnologie wat ontwikkel is vir die Staat, byvoorbeeld verdedigingstegnologie, omgeskakel word vir kommersiële gebruik tot voordeel van die breër gemeenskap. Aangesien tegnologie-kommersialisering 'n hoë-risiko en duur proses is, moet net daardie tegnologieë gekommersialiseer word wat die beste kanse vir sukses het. Heslop, McGregor \& Grifith [1] het die Cloverleaf Model vir die assessering van tegnologie-gereedheid vir kommersialisering ontwikkel. Hierdie model is ge-evalueer en verbeter vir gebruik in die Suid-Afrikaanse omgewing. 


\section{INTRODUCTION}

Heslop, McGregor \& Grifith [1] describes technology as the engine of progress, wealth creation and economic growth. Technology in itself cannot create wealth, but it is the products and services generated through the application of technological inventions or innovations, which creates wealth. According to Agmon \& Von Glinow [2] the ability of a country to maintain a technological lead is a function of accumulated knowledge, resulting from large public investment in education as well as in research and development. Technological capabilities are crucial for defence and security as well as the competitiveness of a nation.

Throughout the world, governments are responsible for a major portion of research and development $(R \& D)$ work. The primary aim of this R\&D effort is generation of technologies to satisfy e.g. the defence needs of the country. To benefit the country as a whole as many of these technologies as possible must be transferred to the private sector to promote economic growth. Commercialisation is the prime method of transferring technology from government R\&D to commercial application and wealth generation. Economic growth is stimulated through both spin-off companies and dual use of technologies. For this reason, Heslop et al [1] states that more and more companies are turning to university and government laboratories for research and the products of research.

Because of the cost, effort and risk associated with commercialisation of technologies, it is crucial that transfer will be attempted with only those technologies with the best chances of success. It is therefore important to assess the 'readiness for commercialisation' of a technology at an early stage. Despite the risk involved in technology commercialisation, the high failure rate and the critical and strategic implications of failure, there has been limited research done and published about how to determine which technology will be successfully commercialised. Presently no standardised method exists in South Africa or elsewhere to evaluate technology readiness for commercialisation.

It was the aim of this research to evaluate a tool for "technology readiness for commercialisation" assessment. This was achieved by testing the Cloverleaf Model, as developed by Heslop et al [1], on selected South African technology commercialisation projects.

\section{MANAGEMENT OF TECHNOLOGY}

\subsection{Technology Defined}

Technology has always been intertwined with society's progress. Khalil [3] states that the application and development of technology is the key to success in global competitiveness. The mere fact of developing new technology is not adequate, as it must be applied in practise to have value and earn a return on investment. This may take place inside the developer's company or sold to outside clients for additional revenue. Khalil [3] defines technology as the knowledge, products, processes, tools, methods and systems employed in the creation of goods or providing services. Technology is in fact the practical implementation of knowledge and a means of aiding human endeavour. It is when scientific knowledge is used and is applied to the things we do in life that knowledge enters the realm of technology. 
Khalil [3] identified the two sources of technology as invention and innovation. Invention is either a concept or creation of a novel technology. It can be a new material, a new manufactured product or a new process to the world. Inventions often follow scientific discoveries, occurring as a result of human ingenuity and imagination. Innovation on the other hand involves the creation of a product, service or process that is new to an organisation or field of expertise. The innovation process involves integration of existing technology and inventions to create a new or improved product, process or system.

\subsection{Technology Transfer}

Rogers \& Takegami [4] states that a technological innovation is fully transferred when it is commercialised into a product that is sold in the marketplace. Khalil [3] defines technology transfer as the process that permits the flow of technology from a source to a receiver. Agmon \& Von Glinow [5] also defines technology transfer as the process by which technological innovations are exchanged between individuals and organisations who are involved with $R \& D$ and those putting technological innovations into use. Technology transfer can also take place through the new product development process. Mogavero \& Shane [6], Davidson, Cetron \& Goldhar [7] and Byrd [8] provided the following modes of technology transfer:

- $\quad$ Passive Mode (Dissemination). This mode consists mainly of knowledge transfer and involves collecting, screening and disseminating information in response to a perceived or stated user demand. Examples are cookbooks, self-teaching manuals etc.

- $\quad$ Semi Active Mode. It moves from self-education and self-retrieval to the intervention of a knowledge or technology transfer agent.

- $\quad$ Active Mode. The active mode involves the participation of transfer agents as well as the interaction between developers and the users of the technology.

According to Davidson et al [7] and Byrd [8] the two main drivers for technology transfer are technology "push" and market "pull". Technology "push" occurs when available technologies are channelled to perceived users in anticipation that the market will need and use them. It happens when an innovator sees an opportunity to profit from a technology that has little or no market at that particular stage. Often an entirely new market is created, based on the novel capacities of the technology. Technology "pull" springs from user needs and requirements. The requirements may originate from firms seeking better technologies to reduce costs or to make improvements in the quality of their existing products. The technology needed may not yet exist, resulting in high-risk projects. However, through this method the technology transfer effort is greatly enhanced because a receptive market already exists.

For the Defence environment, Byrd [8] names three main types of technology transfer:

- $\quad$ Spin-Off. The technology developed to meet a national defence mission is transferred to the private sector, other national agencies or local government. The spin-off technology will be used for purposes other than those for which it was created.

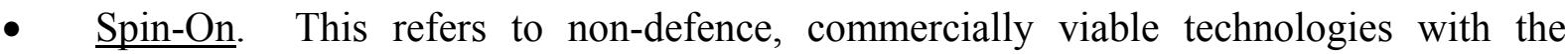
potential for national defence applications. 
- Dual-Use. Dual-use technology is any technology with current or potential military and civil applications. It includes the co-development of a technology by a national defence and non-defence organisation.

\section{TECHNOLOGY COMMERCIALISATION}

Technology commercialisation is a special case of technology transfer. In the simplest form of the technology commercialisation process, technology is developed by one institution and then commercialised for application in the marketplace. Cooper [10] summarised the process of commercialisation of a new product as comprising of a series of steps. These include idea generation, product definition, concept screening, prototype development, concept testing, diagnostic evaluation, preliminary marketing, financial analysis, product development, product testing, and simulated or actual test marketing. Failure to carry out one or more of these steps has been correlated to product failure.

Third parties are often used to assist in the transfer of technology; these are typically called "Technology Transfer Offices" or "Technology Brokers". They act as vendors, transferring the technology from the developer to the customers who then produce a product to sell in the market. In South Africa, Armscor is responsible for managing technology development programmes for the Department of Defence. In an effort to facilitate the transfer of technology to the private sector for commercial use, Armscor established the Technology Exploitation Centre (TEC) as a subsidiary. The objectives of TEC are to identify potential technologies and to analyse their commercial viability. TEC provides expertise in the process of commercialisation and industrialisation of technology. The generic steps of a technology transfer process are:

- Source Technologies. All technologies available for commercialisation are sourced from research institutions, Government agencies, local industry, and international networks.

- Filter the Technologies. All available technologies are filtered to identify the technologies with the highest probability for success. It ensures that time and effort is not wasted on immature technologies or where no market exists.

- Develop a Business Model. A business model is needed to determine how the technology will be produced and sold in the market. This will also indicate feasibility and level of expected success.

- Develop a Detailed Business Plan. The business plan is used to market the technology and to gain investors, producers, customers etc. It is the final evaluation for expected success before implementation and is also used to discard unattractive technologies.

- Implementation. During this phase the implementation of the technology commercialisation plan is monitored and managed.

The three middle steps are used to filter the technologies to ensure only the winners are implemented. It can be interpreted as a stage-gate process where technologies not satisfying criteria are discarded at the end of each step. 


\section{TECHNOLOGY READINESS EVALUATION}

The most crucial step of the technology transfer process is selection of the right technologies to start the process of transfer with. According to Cooper [10] most new product failures are attributed to bringing the wrong product to the market or the right product at the wrong time. Heslop et al [1] states that picking winning technologies amongst other technologies for development from the opportunities presented by R\&D laboratories, is not easy and often a poorly managed process.

A number of researchers have investigated the evaluation of the readiness of technology for commercialisation and developed assessment methodologies. The following are examples of current methodologies:

- $\quad$ Stage Gate New Product Development Process. Cooper [10] has performed extensive research regarding new product success. He noted that the characteristics of successful new products are related to high levels of market attractiveness, sophisticated technology, business and technology synergy, market synergy and competitive advantage. He proposed a Staged Gate Process to guide new product development, which has some similarity with the technology commercialisation process. Cooper [10] recommended that companies use a checklist of "must meet" as well as "should meet" criteria in assessing whether or not to proceed (gates) with a new product development project.

- Brian Twiss [11] listed some of the most important qualitative criteria for evaluation of technologies.

- United States Air Force. As part of the United States Air Force's (USAF) Technology Transfer Handbook [12] the evaluation of technology is addressed as part of the commercialisation process. A preliminary assessment will provide a rank order or grouping of those technologies with the highest to lowest commercialisation potential. Those technologies with high technology transfer potential are candidates for in-depth analysis.

- NASA. According to the NASA Technology Commercialisation Process (NPG 7500_1) [13] commercial potential is often tied to the value of the technology, more specifically to its potential benefits, advantages in the marketplace and impact on profitability. Several essential technical, market and intellectual property issues must be addressed when assessing value.

- $\quad$ Florida State University [14] also developed a guideline for assessing technology readiness for transfer or commercialisation.

The assessment criteria mentioned in the literature can be grouped into four categories: technology readiness, market readiness, commercial readiness, and management readiness as shown in Table 1. Heslop et al [1] identified almost fifty criteria reported by authors in the fields of technology transfer and new product development. He refined them by sending questionnaires to Canadian and United States universities as well as government R\&D laboratories. Heslop's Cloverleaf Model uses the four categories of criteria mentioned above (hence the name 'Cloverleaf'). The Cloverleaf Model provides a method of quantifying the judgments made by the assessor or assessment team of the degree to which each condition is met. The Cloverleaf technology readiness assessment instrument is shown in Figure 1. 


\begin{tabular}{|c|c|c|c|c|c|}
\hline & Cooper & Twiss & US Air Force & NASA & FSU \\
\hline & $\begin{array}{l}\text { Offers unique benefits to } \\
\text { customers or end users. } \\
\text { Offers the customer good } \\
\text { value for money. } \\
\text { Solves a problem the } \\
\text { customer had with } \\
\text { previous products. } \\
\text { Have highly visible } \\
\text { benefits. } \\
\text { This product is higher } \\
\text { quality than competitive } \\
\text { products. }\end{array}$ & $\begin{array}{l}\text { Probability of technical } \\
\text { success. } \\
\text { Development cost and } \\
\text { time. } \\
\text { Patent position. } \\
\text { Availability of R\&D } \\
\text { resources. } \\
\text { Future development. } \\
\text { Environmental effects. }\end{array}$ & $\begin{array}{l}\text { Potential of resulting in a } \\
\text { product. } \\
\text { Maturity of the technology. } \\
\text { Development is required } \\
\text { before fielding the } \\
\text { technology. } \\
\text { Technology strengths. } \\
\text { Technology weaknesses. } \\
\text { Technology ownership. } \\
\text { Ease of replication. }\end{array}$ & $\begin{array}{l}\text { Technology has been } \\
\text { successfully demonstrated in } \\
\text { an advanced prototype. } \\
\text { The product that is better than } \\
\text { the existing and emerging } \\
\text { technologies. }\end{array}$ & $\begin{array}{l}\text { Patent and literature search } \\
\text { completed and clean. } \\
\text { Technology is a basis of a new } \\
\text { industry or company. } \\
\text { Technology is state-of-the-art. } \\
\text { Easy to demonstrate technology. } \\
\text { Identifiable and significant } \\
\text { benefits. } \\
\text { Functioning prototype. } \\
\text { Technology protectable by } \\
\text { patents. }\end{array}$ \\
\hline 冚 & $\begin{array}{l}\text { The market is large. } \\
\text { The market is growing. } \\
\text { It has significant long- } \\
\text { term potential. } \\
\text { No intensive or } \\
\text { aggressive competition is } \\
\text { present. } \\
\text { Competitors serve the } \\
\text { market poorly. }\end{array}$ & $\begin{array}{l}\text { Identifiable need. } \\
\text { Estimated sales. } \\
\text { Timing. } \\
\text { Pricing. } \\
\text { Competition. } \\
\text { Distribution channels. }\end{array}$ & $\begin{array}{l}\text { The need for this } \\
\text { technology. } \\
\text { The potential applications of } \\
\text { the product. } \\
\text { Significance of the need. } \\
\text { Market sales potential. }\end{array}$ & $\begin{array}{l}\text { Need for the product. } \\
\text { Sufficient end users are } \\
\text { identified needing the } \\
\text { innovation. } \\
\text { Users are willing to pay an } \\
\text { acceptable price to provide a } \\
\text { reasonable profit margin. } \\
\text { Value throughout the supply } \\
\text { chain. }\end{array}$ & $\begin{array}{l}\text { Fills identifiable and marketable } \\
\text { need. } \\
\text { Market is sizable and growing. } \\
\text { Large market potential. } \\
\text { Absence of direct competitive } \\
\text { products. } \\
\text { Market accessible (no } \\
\text { competition). } \\
\text { Technology has low dissonance. }\end{array}$ \\
\hline ن & $\begin{array}{l}\text { Sales force distribution. } \\
\text { Customer base. } \\
\text { Production facilities and } \\
\text { personnel. } \\
\text { A sponsor to shepherd } \\
\text { this project. }\end{array}$ & $\begin{array}{l}\text { Manufacturing capability. } \\
\text { Cost of manufacture. } \\
\text { Availability of raw } \\
\text { materials. }\end{array}$ & $\begin{array}{l}\text { Potential partners with } \\
\text { similar technology needs. } \\
\text { Commercial applications. } \\
\text { Commercial strengths. } \\
\text { Commercial weaknesses. }\end{array}$ & $\begin{array}{l}\text { Identification of developers. } \\
\text { Timing of the } \\
\text { commercialisation } \\
\text { Cost of development. } \\
\text { Return on investment. }\end{array}$ & $\begin{array}{l}\text { Prospective licensee identified. } \\
\text { Low financial risk. } \\
\text { Sustainable competitive } \\
\text { advantage. } \\
\text { Conforms to relevant standard. }\end{array}$ \\
\hline 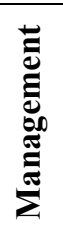 & $\begin{array}{l}\text { A champion to drive the } \\
\text { project forward. }\end{array}$ & & $\begin{array}{l}\text { Intellectual property } \\
\text { position. }\end{array}$ & & $\begin{array}{l}\text { Inventor is technology } \\
\text { champion. } \\
\text { Inventor has realistic } \\
\text { expectations. } \\
\text { Inventor is team player. }\end{array}$ \\
\hline
\end{tabular}

Table 1. Summary of Technology Assessment Parameters 
For each of the criteria conditions below, enter a score for extent to which condition is met where $1=$ not met, 2 =partially met, 3 =fully met. Enter a score from 1 to 3 for level of confidence in the rating where $1=$ low confidence and 3 =high confidence. Multiply the two scores for each and enter the product as the weighted score. Finally, sum the weighted scores for a total score.

\section{Market Readiness}

The technology offers significant identifiable and quantifiable benefits

The product/process has distinct advantages over competing products

The technology has future uses

There is a definable marketable product

A defined market is accessible

The market is a large one

The market is a growing one

The technology has immediate market uses

The technology will be first-to-market

Manufacturing is determined to be feasible

Market Readiness Score (Max 90)

\section{Technology Readiness}

The technology is a new, non-obvious invention The patent and literature search are complete and clear There are no other dominant patents

The technology is state-of-the-art or major breakthrough

The technology is a core or platform technology

No pending publications (Canada only)*

Technology Readiness Score (Max 45 or 54*)

\section{Commercial Readiness}

Prospective licensees are identified

Inventor has industry contacts

Licensee financial support is available for further

development/patenting

There is access to venture capital

A positive return on investment is expected

Royalty/licensing income expected to provide positive net present value

Low marketing costs (Canada only)*

Government support available for additional development (Universities only)**

Commercial Readiness Score (Max 54 or 63* or $72 * *$ )

\section{Management Readiness}

Inventor will champion as a team player

The inventor has realistic expectations for success

The inventor is recognized and established in the field

Commercialisation skills are available

Management capabilities are available

Inventor holds patent (Government labs only)*

Management Readiness Score (Max 45 or $54^{*}$ )

TOTAL SCORE

Extent to which $\quad$ Level of $\quad$ Wtd

Condition is met Confidence Score

\begin{tabular}{|c|c|c|}
\hline Management Readiness Score (Max 45 or $54 *)$ & & $\overline{\text { Subtotal }}$ \\
\hline TOTAL SCORE & & \\
\hline
\end{tabular}

Figure 1: The Cloverleaf Model ${ }^{\mathrm{TM}}$ - technology transfer readiness assessment tool 
Using the Cloverleaf Model, the resulting total scores can be used to provide a cut-off for consideration or for comparing projects. If the score is below $2 / 3$ of the maximum, then it is not likely that most conditions are even partially met and the technology would not stand a good chance of commercialisation at that point in time. However, these initial benchmarks can be adjusted over time by the technology transfer practitioners and adapted by using the experience in their own laboratories. The sub-scores in each of the four areas should also be examined to identify possibilities of improvement. Practitioners can, as needed, amend the tool over time to suit their particular situation, knowing that the fundamental structure is in place for a good evaluation.

\section{CASE STUDIES}

To evaluate the appropriateness of the Cloverleaf Model, four technologies currently in the process of commercialisation by TEC, were evaluated. The four technologies with their respective ratings are shown in Table 2.

\begin{tabular}{|c|c|c|c|c|c|}
\hline Project & $\begin{array}{c}\text { Market } \\
\text { Readiness } \\
(\mathbf{9 0})\end{array}$ & $\begin{array}{c}\text { Technology } \\
\text { Readiness } \\
\mathbf{( 5 4 )}\end{array}$ & $\begin{array}{c}\text { Commercial } \\
\text { Readiness } \\
\mathbf{( 7 1 )}\end{array}$ & $\begin{array}{c}\text { Management } \\
\text { Readiness } \\
\mathbf{( 5 4 )}\end{array}$ & $\begin{array}{c}\text { Total } \\
\text { Score } \\
(\mathbf{2 7 0 )}\end{array}$ \\
\hline $\begin{array}{c}\text { Cataract } \\
\text { Detection } \\
\text { Tool }\end{array}$ & $\begin{array}{c}49 \\
(54 \%)\end{array}$ & $\begin{array}{c}31 \\
(57 \%)\end{array}$ & $\begin{array}{c}33 \\
(46 \%)\end{array}$ & $\begin{array}{c}46 \\
(85 \%)\end{array}$ & $\begin{array}{c}159 \\
(59 \%)\end{array}$ \\
\hline $\begin{array}{c}\text { Portable X- } \\
\text { Ray Machine }\end{array}$ & $\begin{array}{c}53 \\
(59 \%)\end{array}$ & $\begin{array}{c}33 \\
(61 \%)\end{array}$ & $\begin{array}{c}26 \\
(37 \%)\end{array}$ & $\begin{array}{c}30 \\
(56 \%)\end{array}$ & $\begin{array}{c}142 \\
(53 \%)\end{array}$ \\
\hline $\begin{array}{c}\text { Electronic } \\
\text { Device }\end{array}$ & $\begin{array}{c}62 \\
(71 \%)\end{array}$ & $\begin{array}{c}27 \\
(50 \%)\end{array}$ & $\begin{array}{c}28 \\
(39 \%)\end{array}$ & $\begin{array}{c}27 \\
(50 \%)\end{array}$ & $\begin{array}{c}144 \\
(54 \%)\end{array}$ \\
\hline Explosives & 46 & 19 & 39 & 35 & 139 \\
$(51 \%)$ & $(35 \%)$ & $(55 \%)$ & $(65 \%)$ & $(52 \%)$ \\
\hline
\end{tabular}

Table 2. Evaluation of four technologies from TEC

The Cloverleaf Model was found to be a useful tool in identifying problem areas and shortcomings as well as strong points of the technology commercialisation projects. However, the evaluations did not provide all the answers sought. As shown in Table 2 the results for the four assessments fall between 59\% and 52\%, making it impossible to discriminate between "good" and "bad" projects. There is a need to improve the tool as "go / no-go" decisions will be based on the result of the assessment. It was also found that some of the parameters are not applicable to the South African environment and other crucial evaluation parameters needs to be added.

\section{IMPROVED CLOVERLEAF MODEL}

To improve the Cloverleaf Model, some parameters were deleted while others were replaced by updated and more relevant parameters. The parameters needing replacement or change were:

- The technology has immediate market uses. This parameter is addressed by a combination of the other parameters. By omitting this parameter, duplication is reduced and the ratio between market and technology readiness is better balanced. 
- The patent and literature search are complete and clear. There are no other dominant patents. No Pending Publications. These parameters all address the same issue. They should be combined into one parameter or replaced by other more relevant parameters.

- Royalty / licensing income expected to provide positive net present value. Duplication exists as this parameter is already addressed under 'A positive return on investment is expected'.

- Low marketing costs. The total marketing cost is a function of the target market and type of final product, and should not influence the decision on technology readiness for commercialisation. This parameter should be replaced by 'Distribution Network' as the availability of distribution networks will reduce marketing costs. The required distribution network must be affordable and preferably already in place to commercialise the product or technology.

- Commercialisation skills are available. Management capabilities are available. Since TEC is a Technology Transfer Office the availability of management capabilities and commercialisation skills are inherent to the organisations and this parameter provides obvious information.

The current set of parameters cannot comprehensively evaluate the readiness of the technology in the South African environment. The additional parameters required to improve the evaluation are:

- The technology is safe for human use and the environment. If the technology is safe to use with no negative effect on the environment, its rating in technology readiness should increase.

- A technology demonstrator or advanced prototype exists. The benefits of the technology should have been demonstrated by means of a prototype, model or technology demonstrator.

- The inventor has industry backup for $R \& D$ and manufacturing. This parameter focuses on possible backup and facilities available for R\&D and manufacturing that the inventor has from industry.

- Financial risk is low. The financial risk must be acceptable with regard to the required investment and expected profits.

- Distribution networks are available. The required distribution network must be affordable and preferably already in place to commercialise the product or technology.

- The roles and responsibilities of the technology broker are clear. For a healthy partnership with the inventor or owner of the technology the roles and responsibilities of the technology broker should be clear. This will result in a tight-knit team to achieve a successful commercialisation project and prevent any wrong expectations.

The new Improved Cloverleaf Model is shown in Figure 2.

The four technologies from TEC were again evaluated using the Improved Cloverleaf Model. The results are provided in Table 3. 
For each of the criteria conditions below, enter a score for extent to which condition is met where $1=$ not met, 2 =partially met, 3 =fully met. Enter a score from 1 to 3 for level of confidence in the rating where $1=$ low confidence and 3 =high confidence. Multiply the two scores for each and enter the product as the weighted score. Finally, sum the weighted scores for a total score.

\begin{tabular}{|c|c|c|c|}
\hline & $\begin{array}{l}\text { Extent to which } \\
\text { Condition is met }\end{array}$ & $\begin{array}{c}\text { Level of } \\
\text { Confidence }\end{array}$ & $\begin{array}{c}\text { Wtd } \\
\text { Score }\end{array}$ \\
\hline $\begin{array}{l}\text { Market Readiness } \\
\text { The technology offers significant identifiable and quantifiable } \\
\text { benefits } \\
\text { The product has distinct advantages over competing products } \\
\text { The technology has future uses } \\
\text { There is a definable marketable product } \\
\text { A defined market is accessible } \\
\text { The market is a large one } \\
\text { The market is a growing one } \\
\text { The technology will be first-to-market } \\
\text { Manufacturing is determined to be feasible } \\
\text { Market Readiness Score (Max 81) }\end{array}$ & & 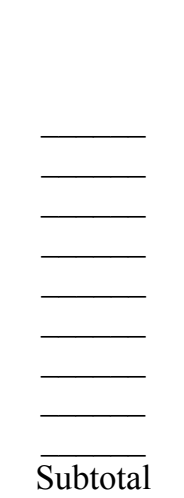 & \\
\hline $\begin{array}{l}\text { Technology Readiness } \\
\text { The technology is a new, non-obvious invention } \\
\text { There are no other dominant patents or pending publications } \\
\text { The technology is state-of-the-art or major breakthrough } \\
\text { The technology is a core or platform technology } \\
\text { The technology is safe for human use and the environment } \\
\text { A prototype or technology demonstrator exist } \\
\text { All raw materials are available for manufacturing } \\
\text { Technology Readiness Score (Max 63) }\end{array}$ & & $\bar{\square} \bar{\square}$ & \\
\hline $\begin{array}{l}\text { Commercial Readiness } \\
\text { Prospective licensees are identified } \\
\text { Inventor has industry backup for R\&D and manufacturing } \\
\text { Licensee financial support is available for further } \\
\text { development/patenting } \\
\text { There is access to venture capital } \\
\text { A positive return on investment is expected } \\
\text { Financial risk is low } \\
\text { Distribution networks are available } \\
\text { Commercial Readiness Score (Max 63) }\end{array}$ & & $\overline{\overline{ }} \overline{ } \overline{ } \overline{\text { Subtotal }}$ & \\
\hline $\begin{array}{l}\text { Management Readiness } \\
\text { Inventor will champion as a team player } \\
\text { The inventor has realistic expectations for success } \\
\text { The inventor is recognized and established in the field } \\
\text { Inventor holds patent } \\
\text { Role and responsibilities of technology broker is clear } \\
\text { Information network relevant market exists } \\
\text { Management Readiness Score (Max 54) }\end{array}$ & & $\overline{\overline{ }} \overline{\overline{ }} \overline{\overline{\text { Subtotal}}}$ & \\
\hline TOTAL SCORE & & & \\
\hline
\end{tabular}

Figure 2. The Improved Cloverleaf Model 


\begin{tabular}{|c|c|c|c|c|c|}
\hline Project & $\begin{array}{c}\text { Market } \\
\text { Readiness } \\
(\mathbf{8 1})\end{array}$ & $\begin{array}{c}\text { Technology } \\
\text { Readiness } \\
\mathbf{( 6 3 )}\end{array}$ & $\begin{array}{c}\text { Commercial } \\
\text { Readiness } \\
\mathbf{( 6 3 )}\end{array}$ & $\begin{array}{c}\text { Management } \\
\text { Readiness } \\
\mathbf{( 5 4 )}\end{array}$ & $\begin{array}{c}\text { Total } \\
\text { Score } \\
(\mathbf{2 7 0})\end{array}$ \\
\hline $\begin{array}{c}\text { Cataract } \\
\text { Detection Tool }\end{array}$ & $\begin{array}{c}68 \\
(84 \%)\end{array}$ & $\begin{array}{c}42 \\
(67 \%)\end{array}$ & $\begin{array}{c}28 \\
(44 \%)\end{array}$ & $\begin{array}{c}38 \\
(70 \%)\end{array}$ & $\begin{array}{c}176 \\
(67 \%)\end{array}$ \\
\hline $\begin{array}{c}\text { Portable X-Ray } \\
\text { Machine }\end{array}$ & 26 & 24 & 13 & 15 & 78 \\
$(32 \%)$ & $(38 \%)$ & $(21 \%)$ & $(28 \%)$ & $(30 \%)$ \\
\hline $\begin{array}{c}\text { Electronic } \\
\text { Device }\end{array}$ & 56 & 33 & 22 & 27 & 138 \\
\hline Explosives & 40 & $(59 \%)$ & $(35 \%)$ & $34 \%)$ & $(53 \%)$ \\
\hline$(49 \%)$ & $(33 \%)$ & $(48 \%)$ & 34 & 125 \\
$(63 \%)$ & $(48 \%)$ \\
\hline
\end{tabular}

Table 3. Re-evaluation of technologies from TEC

As shown in Table 3 the results for the four assessments now fall between $67 \%$ and $30 \%$, making it possible to discriminate between "good" and "bad" projects. Generally it is felt that the Improved Cloverleaf Model is a better tool for assessment of technology readiness for commercialisation. Although this tool could be further improved, the evaluation parameters used and the new loadings have improved the quality of decision-making regarding selection of technologies for commercialisation. Another improvement is the utilisation of an information leaflet guiding the rating of the parameters.

\section{CONCLUSION}

During the study the importance of effective technology commercialisation became clear. To gain from R\&D expenditure, technology should be converted to products. Often the organisation responsible for inventions and innovations are not suited to produce and market a specific technology or product. This is especially true for commercialisation of technology that was developed by a government for defence purposes. If the funds spent are to be of benefit to the country as a whole, some technologies must be transferred to the private sector. Therefore, technology commercialisation forms an important part of a national technology strategy.

To commercialise defence related technology is a difficult and lengthy process. To commercialise these technologies it is necessary to find the right balance between market "pull" and technology "push". Therefore a prerequisite for a successful technology commercialisation effort is to transfer the right technologies to the right market at the right time. The commercial organisation or licensee must invest in the final development of a product. After identifying candidates for technology transfer, they must be assessed for commercialisation readiness. This will ensure that only those technologies with a high probability for success will be commercialised. This research project has evaluated and improved the Cloverleaf Model from Heslop et al [1].

The Cloverleaf Model evaluates the readiness for commercialisation of a technology in terms of market, technology, commercialisation and management readiness. Four technology commercialisation projects from TEC, at different stages in the process, were evaluated using the Cloverleaf Model. The first round of assessments were not 
very successful, as the results did not always reflect the true state of the commercialisation projects. By evaluating the original Cloverleaf Model, the following conclusions were made:

- The Cloverleaf Model is not only a tool to evaluate readiness for commercialisation of new technologies, but can be used to audit current commercialisation projects to identify problem areas.

- $\quad$ The model does not discriminate sufficiently making it impossible to make "go $\backslash$ no-go" decisions on individual technologies. Furthermore, because the Cloverleaf Model is based on perceptions and dependant on the expertise of the evaluator/s, it should rather be used to rank a number of technologies to decide which are the better candidates for commercialisation.

- The Cloverleaf Model should be adapted to the specific environment, as well as the type of technology to be commercialised for accurate evaluation. Different environments have different characteristics and requirements to be addressed in technology commercialisation.

- Those using the Cloverleaf Model require experience in commercialising technology. The value of the assessment will be enhanced if the evaluator has indepth knowledge of the parameters.

- There will be different interpretations of the different parameters by different people. Therefore guidelines are needed to ensure a standardised and repeatable tool. Also it will be best if the same team of experts evaluates all proposed technologies suggested for commercialisation.

- Where possible the same team should assess all the technologies under evaluation to ensure a standardised interpretation of the parameters and rating thereof.

The Cloverleaf Model was improved with inputs from literature and conclusions from the evaluation of four cases. Guidelines for using the Improved Cloverleaf Model were constructed to help the evaluators and standardise the tool when used by different people. The same four technologies as before were re-evaluated using the Improved Cloverleaf Model along with the guidelines. The results were improved and projected a more realistic picture of the current situation. The following conclusions can be made concerning the Improved Cloverleaf Model:

- It would be useful to record the reasons for decisions on each and every rating. This will be useful during re-evaluations at a later stage in the project for progress evaluation.

- The assessments must be performed within the shortest time period possible to ensure a consistency of mindsets and paradigms.

- The Improved Cloverleaf Model does provide better discrimination between technologies, making it possible to make "go / no-go" decisions. It is however still felt that it should rather be used to rank the available technologies for making a decision on which to commercialise.

- The tool can be used on on-going technology commercialisation projects to identify strong points and problem areas. 


\section{REFERENCES}

[1] Heslop, L.A. McGregor, E. Grifith, M., 2001 "Development of a Technology Readiness Assessment Measure: The Cloverleaf Model of Technology Transfer", Journal of Technology Transfer, Vol. 26, p 369 - 84.

[2] Agmon, T. Von Glinow, M.A.Y., 1991. "Technology transfer in International Business", Oxford University Press, p 79-102.

[3] Khalil T.M., 2000. "Management of Technology", McGraw-Hill.

[4] Rogers, E. M. Takegami, S. Yin, J., 2001 "Lessons Learnt About Technology Transfer", Technovation Vol 21, p 253 - 261.

[5] Agmon, T. Von Glinow, M. A. Y., 1991. "Technology transfer in International Business", Oxford University Press, p $103-120$.

[6] Mogavero, L.N., Shane, R.S., 1982. "What Every Engineer Should Know About Technology transfer and Innovation", Marcel Dekker Inc.

[7] Davidson, H.F. Cetron, M. J. Goldhar, J.D., 1974. “Technology transfer”, Noordhoff, Leiden.

[8] Byrd, R.C., "National Technology Transfer Centre", http://www.nttc.com, Visited 30 February 2002.

[9] Carayanis, E. G. Rogers and Takegami, E. M. Kurihara, K. Allbritton, M. M., 1998 "High-Technology Spin-Offs from R\&D Laboratories and Research Universities", Technovation Vol 18, p $1-11$.

[10] Cooper, R.G., 1993 "Winning at New Products - Accelerating the Process from Idea to Launch", $2^{\text {nd }}$ Edition, Addison Wesley Publishing Company, Inc.

[11] Twiss, B.C., 1986 “Managing Technological Innovation”, Longman Group Limited.

[12] “Air Force Technology Transfer Handbook", http://www.afrl.af.mil/techtran/handbk, Visited 2 May 2002.

[13] "NASA Technology Commercialisation Process", http://nodis3.gsfc.nasa.gov/library/, Visited 17 June 2002.

[14] "Florida State University - Technology Transfer", http://www.techtransfer.fsu.edu/, Visited 17 June 2002. 
